\title{
EVALUATION OF COGNITIVE FUNCTION AMONG NEWLY DIAGNOSED IDIOPATHIC EPILEPTIC PATIENTS
}

\author{
Samia A. Mohammad ${ }^{(1)}$, Mahmoud H. El-Rakawy ${ }^{(1)}$, Nahed S. Ahmad ${ }^{(1)}$, \\ Heba H. Al-Shahawy ${ }^{(2)}$, Mohammad M. Fouad ${ }^{(1}$ and Ehab Mostafa Ahmed ${ }^{(3)}$
}

(1) Department of Neurology Faculty of Medicine, Ain Shams University

${ }^{(2)}$ Department of Psychiatry

Faculty of Medicine, Ain Shams

University

(3) Department of Neurology

Faculty of Medicine, Helwan

University

Corresponding :

Ehab Mostafa Ahmed

Mobile: 01112004406

E mail:

ehab_mostafa1982@hotmail.com

Received: $21 / 8 / 2019$

Accepted: 19/9/2019

\begin{abstract}
:
Background: Neuropsychological study of new-onset idiopathic epilepsy is considered an exciting opportunity to document cognitive effects of epilepsy before initiation of antiepileptic drugs. Recent studies revealed significant affection of executive functions in new onset seizure without medication.
\end{abstract}

Aim of the Work: To evaluate cognitive functions including (IQ, visual memory and executive functions) in patients with idiopathic epilepsy at onset of disorder before drug treatment or within one week of treatment.

Patients and Methods: An observational case -control study was conducted on 30 patients with new onset idiopathic epilepsy recruited from the outpatient clinic of the department of neurology (Ain Shams University) and 30 healthy cross matched control in the period from June 2016 to June 2018. Both patients and control were subjected to cognitive assessments (Wechsler IQ, Benton visual retention test and Wisconsin card sorting test).

Results:In our study we found significant poor performance of patient group before treatment compared to control group in all domains of intellectual abilities measured by Wechsler IQ test (verbal $I Q$, performance IQ and total IQ), visual memory measured by Benton visual retention test (obtained correct score, expected error scores and difference between them, obtained error score and expected error score and difference between them) and executive functions measured by Wisconsin card sorting test (conceptual level, category completed, perseverative errors and non-perseverative errors).

Conclusion: cognitive functions impairment including (intellectual level, visual memory and executive functions) were found in patients with idiopathic epilepsy at onset of epilepsy and before treatment.

Key words: cognitive Function, idiopathic Epilepsy

\section{INTRODUCTION:}

The idiopathic epilepsies (IE) are a cluster of syndromes presumed to be of genetic origin. It is consisted of two groups of epilepsy: idiopathic generalized epilepsy (IGE) and Idiopathic focal epilepsy (IFE) ${ }^{(1)}$.

Many epilepsies directly impact on a child's brain and, therefore, on their cognitive development, language and social skills ${ }^{(2)}$. Cognition in epilepsy is complex because problems may be intrinsic to the epilepsy itself and its underling neuropathology; seizures can affect cognition as can interictal EEG activity, psychosocial and family problems ${ }^{(3)}$.

Even in children with idiopathic epilepsy, the different seizure types carry with them the 
possibility of different levels of various impairments in cognitive abilities ${ }^{(\mathbf{3})}$, parents reporting learning difficulties and memory problems even in this benign epilepsy with obvious implications for day to day functioning ${ }^{(4)}$.

Recent study revealed significant affection of executive function in new onset seizure without medication ${ }^{(5)}$.

Neuropsychological study of new-onset epilepsy was considered to present an exciting opportunity to document cognitive effects of epilepsy before initiation of antiepileptic drugs and to establish a baseline that would enable evaluation of changes over time. Existing studies have already shown certain cognitive deficits in children $^{(6,7)}$, adults and the elderly ${ }^{(8)}$ in newonset epilepsy. A variety of investigative approaches have been used, from short screening batteries to longer evaluations, and the tasks that have been used vary. A common thread among studies is an emphasis on attentional and "executive function" tasks, and comparatively less on memory, especially visuoperceptual memory $^{(9)}$.

Proper and early identification of cognitive dysfunctions in patients with idiopathic epilepsy is necessary to provide early developmental interventions, appropriate school programming, vocational counseling, supportive work settings, and a safe environment for promotion of independence across the life $\operatorname{span}^{(3)}$.

\section{PATIENTS AND METHODS:}

This observational case -control study was conducted on 60 subjects recruited from the outpatient clinic of the department of neurology (Ain Shams University) located in Eastern Cairo, and serves a catchment area of about the third of Greater Cairo as well. They were equally divided into two groups, patient group and control group.

\section{Patients group:}

A convenient sample of 30 patients with recent onset idiopathic epilepsy before or within the first 7 days of starting antiepileptic medication.

The study included patients from both sexes with ages 8 years old and more, with recent onset idiopathic epilepsy before or within the first 7 days of starting antiepileptic medication, IQ test 80 or more, who at least can read and write.

While patients with seizures secondary to drugs, infection, mass lesion, demyelination, degenerative diseases, metabolic disease or trauma., seizures occurring 24 hours preceding cognitive functions assessment, patients having other medical, neurological or psychiatric diseases, patient receiving any medication other than antiepileptic medication, patients with past history of substance abuse were excluded.

\section{Control group:}

30 healthy volunteers matched for age, sex and educational level with the patient group recruited from offspring of the employee of El Demerdash hospital.

\section{Exclusion criteria for control group:}

Individuals who have past history of any medical, neurological, psychiatric disorder, IQ less than 80 were excluded from the study.

\section{Procedures:}

\section{1) Approval}

We got approval of the study from ethical committee of faculty of medicine Ain Shams University.

\section{2) Written informed consent}

A written informed consent was obtained from caregiver of both patient and control groups involved in the study contained the name of the study, its aim, detailed description of the procedure. 


\section{3) Study proper}

\section{Patient group was subjected to:}

1. Semi structured sheet: this sheet was done by the researcher under supervision of supervisors including sociodemographic and clinical characteristics of patients

\section{Clinical examination including:}

- Detailed general examination.

- Complete neurological examination.

\section{Electroencephalogram (EEG):}

- EEG was done for all patients at baseline for diagnosis of idiopathic epilepsy.

\section{Neuroimaging:}

Magnetic Resonance Imaging of the brain with thin coronal cuts (epilepsy protocol).

5. Cognitive functions were performed by expert psychologist including baseline before treatment or within one week of treatment.

- Intelligence assessment measured by Wechsler Intelligence Scale for children (WISC-III) for (Wechsler, 1991).

- Executive functions assessment measured by Wisconsin Card Sorting Test (WCST) the computerized version for (WCST, 1987).

- Visual memory, visual perception and visuo-constructive abilities Benton Visual Retention Test-Revised (BVRTR) for assessment of (Benton, 1963).

\section{Control group was subjected to:}

1- Full detailed history to exclude any neurological, medical or psychiatric disorders.

\section{2- Complete neurological examination.}

3- Cognitive functions: the same like patient group.

\section{Statistical analysis:}

Recorded data were analyzed using the statistical package for social sciences, version 20.0 (SPSS Inc., Chicago, Illinois, USA). Quantitative data were expressed as mean \pm standard deviation (SD). Qualitative data were expressed as frequency and percentage.

The following tests were done: Independent-samples t-test of significance was used when comparing between two means. Paired sample t-test of significance was used when comparing between related samples. Chi-square ( 2 ) test of significance was used in order to compare proportions between qualitative parameters. Pearson's correlation coefficient (r) test was used to assess the degree of association between two sets of variables the confidence interval was set to $95 \%$ and the margin of error accepted was set to $5 \%$. So, the p-value was considered significant as the following: Probability (P-value) P-value $<0.05$ was considered significant. P-value $<0.001$ was considered as highly significant. P-value $>$ 0.05 was considered insignificant.

\section{RESULTS:}

\section{- Sociodemo graphic data of patient} group table (1):

The age ranged from 8-15 years with the mean age of $10.83 \pm 2.05$ years. The patient group consisted of 17 males $(56.7 \%$ of the group) and 13 females (43.3\% of the group). Years of education ranged from 2-8 years with the mean of $4.33 \pm 1.83$ years. 
Samia A. Mohammad, et al.,

Table (1): Socio-demographic data of patient group

\begin{tabular}{|l|c|}
\hline Socio-demographic data & $\begin{array}{c}\text { Patient group } \\
(\mathbf{n}=30)\end{array}$ \\
\hline Age (years) & $10.83 \pm 2.05$ \\
\hline Mean \pm SD & $8-15$ \\
\hline Range & $17(56.7 \%)$ \\
\hline Sex & 13 \\
\hline Male & \\
\hline Female & $4.33 \pm 1.83$ \\
\hline Years of Education & $2-8$ \\
\hline Mean \pm SD & $19(63.3 \%)$ \\
\hline Range & $11(36.7 \%)$ \\
\hline Birth order &
\end{tabular}

$\mathrm{SD}=$ standard deviation; $\mathrm{n}=$ number

\section{- Clinical characteristics of patient} group table (2):

The age of patient at onset of disease ranged from 8-15 years with the mean age $10.83 \pm 2.05$ years. As regards family history (FH) of epilepsy there were $10(33.3 \%)$ patients with negative $\mathrm{FH}$ of epilepsy while $20(66.67 \%)$ patients with positive FH of epilepsy.

FH of consanguinity was positive in 16 $(53.3 \%)$ patients while negative in 14 (46.7\%) patients. The duration since the first seizure till recruitment to the study ranged from 3- 60 days with the mean of $24.97 \pm 16.03$ days. Frequency of seizures per week was once per week in $21(70.0 \%)$

Table (2):Clinical characteristics of patient group

\begin{tabular}{|c|c|}
\hline \multicolumn{1}{|c|}{ Clinical characteristics } & $\begin{array}{c}\text { Patient group } \\
\text { (number=30) }\end{array}$ \\
\hline Age at onset (years) & $8-15[10.83 \pm 2.05]$ \\
\hline Family history of Epilepsy & $20(66.7 \%)$ \\
\hline Positive & $10(33.3 \%)$ \\
\hline Negative & $16(53.3 \%)$ \\
\hline Family history of Consanguinity & $14(46.7 \%)$ \\
\hline Positive & $3-60[24.97 \pm 16.03]$ \\
\hline Negative & $21(70.0 \%)$ \\
\hline Duration since first seizure till recruitment to study & $3(10.0 \%)$ \\
\hline Frequency of seizures per week & $6(20.0 \%)$ \\
\hline 1 & $12(40.0 \%)$ \\
\hline 2 & $10(33.3 \%)$ \\
\hline more than 10
\end{tabular}

patients, twice per week in $3(10.0 \%)$ patients and more than 10 per week in 6 $(20.0 \%)$ patients. Total number of seizure was more than 10 in 6 patients $(20.0 \%), 2$ in 12 patients $(40 \%), 3$ in 10 patients $(33.3 \%)$, 4 in one patient $(3.3 \%)$ and 6 in one patient $(3.3 \%)$.

The type of seizure was GTC only in $15(50 \%)$ patients, GTC + Myoclonus in 7 $(23.3 \%)$ patients, absence only in $4(13.3 \%)$ patients, Absence + GTC in $2(6.7 \%)$ patients and rolandic seizure in $2(6.7 \%)$ patients. There was postictal confusion in 24 $(80.0 \%)$ patients while negative in $6(20 \%)$ patients. 


\begin{tabular}{|l|c|}
\hline 4 & $1(3.3 \%)$ \\
\hline 6 & $1(3.3 \%)$ \\
\hline More than 10 & $6(20.0 \%)$ \\
\hline Type of seizure & $15(50.0 \%)$ \\
\hline GTC & $7(23.3 \%)$ \\
\hline GTC + Myoclonus & $4(13.3 \%)$ \\
\hline Absence & $2(6.7 \%)$ \\
\hline Absence + GTC & $2(6.7 \%)$ \\
\hline Rolandic seizure \\
\hline Postictal confusion & $24(80.0 \%)$ \\
\hline Positive & $6(20.0 \%)$ \\
\hline Negative & \\
\hline
\end{tabular}

As regards EEG findings, no abnormality detected (NAD) was found in 5 (16.7\%) patients, typical absence findings were detected in $4(13.3 \%)$ patients, generalized spike wave activity in $19(63.3 \%)$ patients and centro-temporal spikes in $2(6.7 \%)$ patients.

As regards the diagnosis, half of the patients $(50.0 \%)$ were diagnosed as Idiopathic generalized epilepsy with GTC only, 7 (23.3\%) patients as Juvenile myoclonic epilepsy, $4(13.3 \%)$ patients as Childhood absence epilepsy, 2 (6.7\%) patients as Juvenile absence epilepsy, and lastly $2(6.7 \%)$ patients as Benign childhood epilepsy with centrotemporal spikes (Rolandic epilepsy).

Table (3): EEG findings and diagnosis distribution of patient group

\begin{tabular}{|c|c|}
\hline & Patient group $(n=30)$ \\
\hline \multicolumn{2}{|l|}{ EEG findings } \\
\hline Generalized spike wave activity & $19(63.3 \%)$ \\
\hline No abnormality detected (NAD) & $5(16.7 \%)$ \\
\hline Typical absence(generalized 3HZ spike and wave activity & $4(13.3 \%)$ \\
\hline Rolandic (centro temporal spikes) & $2(6.7 \%)$ \\
\hline \multicolumn{2}{|l|}{ Diagnosis } \\
\hline Idiopathic generalized epilepsy with GTC only & $15(50.0 \%)$ \\
\hline Juvenile myoclonic epilepsy & $7(23.3 \%)$ \\
\hline Childhood absence epilepsy & $4(13.3 \%)$ \\
\hline Juvenile absence epilepsy & $2(6.7 \%)$ \\
\hline Benign childhood epilepsy with centro-temporal spikes (Roland & $2(6.7 \%)$ \\
\hline
\end{tabular}

I- Comparison between patients and control groups as regards sociodemographic data, IQ test, Benton visual retention test and Wisconsin card sorting test (Tables $4,5,6,7$ ).

- Comparison between patient group and control group as regards sociodemographic data:
The comparison between patient and control groups showed no statistically significance differences as regards sociodemographic data (age, sex, years of education and order of birth). 
Samia A. Mohammad, et al.,

Table (4): Comparison between patient group and control group as regards socio-demographic data

\begin{tabular}{|c|c|c|c|c|}
\hline Socio-demographic data & $\begin{array}{c}\text { Patient group } \\
(n=30)\end{array}$ & $\begin{array}{c}\text { Control group } \\
(n=30)\end{array}$ & $\mathbf{t} / \chi^{2} \#$ & p-value \\
\hline \multicolumn{5}{|l|}{ Age (years) } \\
\hline Mean \pm SD & $10.83 \pm 2.05$ & $10.87 \pm 1.94$ & \multirow[t]{2}{*}{$\mathrm{t}=0.004$} & \multirow[t]{2}{*}{0.949} \\
\hline Range & $8-15$ & $8-14$ & & \\
\hline \multicolumn{5}{|l|}{ Sex } \\
\hline Male & $17(56.7 \%)$ & $16(53.3 \%)$ & \multirow[t]{2}{*}{$\mathrm{X} 2=0.067$} & \multirow[t]{2}{*}{0.795} \\
\hline Female & $13(43.3 \%)$ & $14(46.7 \%)$ & & \\
\hline \multicolumn{5}{|l|}{ Years of Education } \\
\hline Mean \pm SD & $4.33 \pm 1.83$ & $4.07 \pm 1.86$ & \multirow[t]{2}{*}{$\mathrm{t}=0.315$} & \multirow[t]{2}{*}{0.577} \\
\hline Range & $2-8$ & $1-7$ & & \\
\hline \multicolumn{5}{|l|}{ Order of birth } \\
\hline $1-2$. & $19(63.3 \%)$ & $19(63.3 \%)$ & \multirow[t]{2}{*}{$\mathrm{X} 2=0.000$} & \multirow[t]{2}{*}{1.000} \\
\hline $3-4$. & $11(36.7 \%)$ & $11(36.7 \%)$ & & \\
\hline
\end{tabular}

$\mathrm{t}$ - independent Sample t-test; $\# \mathrm{x}^{2}$ : Chi-square test; $\mathrm{n}=$ number ; $\mathrm{SD}=$ standard deviation

- The comparison between patient and control groups as regards the results of Wechsler IQ test showed that table (5):

The total IQ scores were significantly lower among the patient group compared to control group. It ranged from 80-110 with mean of $95.17 \pm 9.00$ in the patient group compared to a range of $91-131$ and mean of $112.80 \pm 9.38$ in the control group $(\mathrm{p}<0.001)$.

The verbal IQ scores were significantly lower among the patient group compared to control group. It ranged from 80-114 with mean of $96.70 \pm 10.46$ in the patient group compared to a range of $92-131$ and mean of $113.13 \pm 9.95$ in the control group $(p<0.001)$. All the parameters of verbal IQ were significantly lower among the patient group compared to control group. The scores of comprehension ranged from 5-15 with mean of $10.67 \pm 2.71$ in the patient group compared to a range of 8-18 and mean of $13.90 \pm 2.52$ in the control group $(\mathrm{p}<0.001)$. The scores of arithmetic ranged from 5-13 with mean of $8.17 \pm 2.38$ in the patient group compared to a range of 7-15 and mean of $10.57 \pm 2.39$ in the control group $(p<0.001)$. The scores of digit span ranged from 4-13 with mean of $7.37 \pm 2.11$ in the patient group compared to a range of $7-15$ and mean of $10.00 \pm 2.21$ in the control group $(p<0.001)$.The scores of similarities ranged from 5-14 with mean of $9.03 \pm 2.28$ in the patient group compared to a range of 7-15 and mean of $11.80 \pm 2.27$ in the control group $(p<0.001)$.

The performance IQ scores were significantly lower among the patient group compared to control group. It ranged from 80-117 with mean of $96.33 \pm 9.50$ in the patient group compared to a range of 92-132 and mean of $112.63 \pm 9.38$ in the control group $(\mathrm{p}<0.001)$. All the parameters of performance IQ were significantly lower among the patient group compared to control group. The scores of picture completion ranged from 6-12 with mean of $9.30 \pm 1.49$ in the patient group compared to a range of 815 and mean of $10.57 \pm 1.57$ in the control group ( $\mathrm{p}=0.002)$. The scores of block design ranged from 4-11 with mean of $7.63 \pm 1.77$ in the patient group compared to a range of 7 15 and mean of $10.23 \pm 2.06$ in the control group $(p<0.001)$. The scores of digit symbol ranged from 5-14 with mean of $8.90 \pm 1.90$ in the patient group compared to a range of 819 and mean of $12.93 \pm 2.61$ in the control group ( $<<0.001)$. 
Table (5): Comparison between patient group and control group as regards Wechsler IQ test

\begin{tabular}{|c|c|c|c|c|}
\hline Wechsler IQ Test & $\begin{array}{c}\text { Patient group } \\
(n=30)\end{array}$ & $\begin{array}{c}\text { Control group } \\
(n=30)\end{array}$ & t-test & p-value \\
\hline \multicolumn{5}{|l|}{ Verbal IQ } \\
\hline \multicolumn{5}{|l|}{ Comprehension } \\
\hline Mean \pm SD & $10.67 \pm 2.71$ & $13.90 \pm 2.52$ & \multirow[t]{2}{*}{22.889} & \multirow[t]{2}{*}{$<0.001$} \\
\hline Range & $5-15$ & $8-18$ & & \\
\hline \multicolumn{5}{|l|}{ Arithematic } \\
\hline Mean \pm SD & $8.17 \pm 2.38$ & $10.57 \pm 2.39$ & \multirow[t]{2}{*}{15.207} & \multirow[t]{2}{*}{$<0.001$} \\
\hline Range & $5-13$ & $7-15$ & & \\
\hline \multicolumn{5}{|l|}{ Digit span } \\
\hline Mean \pm SD & $7.37 \pm 2.11$ & $10.00 \pm 2.21$ & \multirow[t]{2}{*}{22.265} & \multirow[t]{2}{*}{$<0.001$} \\
\hline Range & $4-13$ & $7-15$ & & \\
\hline \multicolumn{5}{|l|}{ Similarities } \\
\hline Mean \pm SD & $9.03 \pm 2.28$ & $11.80 \pm 2.27$ & \multirow[t]{2}{*}{22.215} & \multirow[t]{2}{*}{$<0.001$} \\
\hline Range & $5-14$ & $7-15$ & & \\
\hline \multicolumn{5}{|l|}{ Performance IQ } \\
\hline \multicolumn{5}{|l|}{ Picture completion } \\
\hline Mean \pm SD & $9.30 \pm 1.49$ & $10.57 \pm 1.57$ & \multirow[t]{2}{*}{10.289} & \multirow[t]{2}{*}{0.002} \\
\hline Range & $6-12$ & $8-15$ & & \\
\hline \multicolumn{5}{|l|}{ Block design } \\
\hline Mean \pm SD & $7.63 \pm 1.77$ & $10.23 \pm 2.06$ & \multirow[t]{2}{*}{27.44} & \multirow[t]{2}{*}{$<0.001$} \\
\hline Range & $4-11$ & $7-15$ & & \\
\hline \multicolumn{5}{|l|}{ Digit symbol } \\
\hline Mean \pm SD & $8.90 \pm 1.90$ & $12.93 \pm 2.61$ & \multirow[t]{2}{*}{46.776} & \multirow[t]{2}{*}{$<0.001$} \\
\hline Range & $5-14$ & $8-19$ & & \\
\hline \multicolumn{5}{|l|}{ Verbal IQ } \\
\hline Mean \pm SD & $96.70 \pm 10.46$ & $113.13 \pm 9.95$ & \multirow[t]{2}{*}{38.874} & \multirow[t]{2}{*}{$<0.001$} \\
\hline Range & $80-114$ & $92-131$ & & \\
\hline \multicolumn{5}{|l|}{ Performance IQ } \\
\hline Mean $\pm \mathrm{SD}$ & $96.33 \pm 9.50$ & $112.63 \pm 9.38$ & \multirow[t]{2}{*}{44.696} & \multirow[t]{2}{*}{$<0.001$} \\
\hline Range & $80-117$ & $92-132$ & & \\
\hline \multicolumn{5}{|l|}{ Total IQ } \\
\hline Mean \pm SD & $95.17 \pm 9.00$ & $112.80 \pm 9.38$ & 55.218 & $<0.001$ \\
\hline Range & $80-110$ & $91-131$ & & \\
\hline
\end{tabular}

t-Independent Sample t-test; $\quad \mathrm{SD}=$ standard deviation ; $\mathrm{n}=$ number

- The comparison between patient and control groups as regards the results of Benton visual retention test showed that table (6):

The obtained correct scores (OCS) were significantly lower among the patient group compared to control group. It ranged from 1-6 with mean of $2.83 \pm 1.37$ in the patient group compared to a range of 4-9 and mean of $6.50 \pm 1.33$ in the control group $(p<0.001)$. The expected correct scores (ECS) were significantly lower among the patient group compared to control group. It ranged from 3-8 with mean of6.07 \pm 1.28 in the patient group compared to a range of 4-9 and mean of $6.83 \pm 1.21$ in the control group $(p=0.020)$. The differences between OCS and ECS were significantly higher among the patient group compared to control group. It ranged from $0-13$ with mean of $3.57 \pm$ 2.19 in the patient group compared to a range of $0-2$ and mean of $0.93 \pm 0.78$ in the control group $(p<0.001)$.

The obtained error scores (OES) were significantly higher among the patient group compared to control group it ranged from 515 with mean of $10.37 \pm 2.11$ in the patient 
group compared to a range of 1-8 and mean of $4.50 \pm 1.87$ in the control group $(p<0.001)$. The expected error scores (EES) were significantly higher among the patient group compared to control group it ranged from 410 with mean of $6.43 \pm 1.55$ in the patient group compared to a range of 1-8 and mean of $4.40 \pm 1.85$ in the control group $(p<0.001)$. The difference between The obtained error scores and the expected error scores (EES) were significantly higher among the patient group compared to control group it ranged from 2-8 with mean of $4.27 \pm 1.57$ in the patient group compared to a range of $0-3$ and mean of $1.23 \pm 0.68$ in the control group $(\mathrm{p}<0.001)$.

Table (6):Comparison between patient group and control group as regards Benton visual retention test

\begin{tabular}{|c|c|c|c|c|}
\hline $\begin{array}{c}\text { Benton Visual Retention Test } \\
\text { (BVRT) }\end{array}$ & $\begin{array}{l}\text { Patient group } \\
(n=30)\end{array}$ & $\begin{array}{c}\text { Control group } \\
(n=30)\end{array}$ & t-test & p-value \\
\hline \multicolumn{5}{|l|}{ OCS (obtained correct scores) } \\
\hline Mean \pm SD & $2.83 \pm 1.37$ & $6.50 \pm 1.33$ & \multirow[t]{2}{*}{110.694} & \multirow[t]{2}{*}{$<0.001$} \\
\hline Range & $1-6$ & $4-9$ & & \\
\hline \multicolumn{5}{|l|}{ ECS (expected correct scores) } \\
\hline Mean \pm SD & $6.07 \pm 1.28$ & $6.83 \pm 1.21$ & \multirow[t]{2}{*}{5.68} & \multirow[t]{2}{*}{0.020} \\
\hline Range & $3-8$ & $4-9$ & & \\
\hline \multicolumn{5}{|c|}{ DIFF(difference between OCS and ECS) } \\
\hline Mean \pm SD & $3.57 \pm 2.19$ & $0.93 \pm 0.78$ & \multirow[t]{2}{*}{38.37} & \multirow[t]{2}{*}{$<0.001$} \\
\hline Range & $0-13$ & $0-2$ & & \\
\hline \multicolumn{5}{|l|}{ OES(obtained error scores) } \\
\hline Mean \pm SD & $10.37 \pm 2.11$ & $4.50 \pm 1.87$ & \multirow[t]{2}{*}{129.925} & \multirow[t]{2}{*}{$<0.001$} \\
\hline Range & $5-15$ & $1-8$ & & \\
\hline \multicolumn{5}{|l|}{ EES(expected error scores) } \\
\hline Mean \pm SD & $6.43 \pm 1.55$ & $4.40 \pm 1.85$ & \multirow[t]{2}{*}{21.339} & \multirow[t]{2}{*}{$<0.001$} \\
\hline Range & $4-10$ & $1-8$ & & \\
\hline \multicolumn{5}{|c|}{ DIFF (difference between OES and EES) } \\
\hline Mean \pm SD & $4.27 \pm 1.57$ & $1.23 \pm 0.68$ & \multirow[t]{2}{*}{93.918} & \multirow[t]{2}{*}{$<0.001$} \\
\hline Range & $2-8$ & $0-3$ & & \\
\hline
\end{tabular}

t-Independent Sample t-test; $\mathrm{SD}=$ standard deviation; $\mathrm{n}=$ number

- The comparison between patient and control groups as regards the results of Wisconsin card sorting test showed that table (7):

The category completed scores were significantly lower among the patient group compared to control group. It ranged from 16 with mean of $4.37 \pm 1.77$ in the patient group compared to a range of 6-6 and mean of $6.00 \pm 0.00$ in the control group $(p<0.001)$. The conceptual level scores were significantly lower among the patient group compared to control group. It ranged from $16-88$ with mean of $56.63 \pm 19.76$ in the patient group compared to a range of $60-88$ and mean of $69.10 \pm 8.12$ in the control group $(p=0.002)$. The conceptual level $\%$ scores were significantly lower among the patient group compared to control group. It ranged from 13-90 with mean of $51.63 \pm$ 21.46 in the patient group compared to a range of 66-88 and mean of $78.03 \pm 6.54$ in the control group $(p<0.001)$.

The perseverative responses scores were significantly higher among the patient group compared to control group. It ranged from 4-102 with mean of $27.97 \pm 25.16$ in the patient group compared to a range of 4-32 and mean of $9.07 \pm 5.55$ in the control group $(p<0.001)$. The perseverative responses $\%$ scores were significantly higher among the patient group compared to control group. It ranged from 5-80 with mean of $23.63 \pm 18.82$ in the patient group compared to a range of 5- 
25 and mean of $9.73 \pm 3.98$ in the control group $(\mathrm{p}<0.001)$.

The perseverative errors scores were significantly higher among the patient group compared to control group. It ranged from 480 with mean of $27.20 \pm 20.30$ in the patient group compared to a range of 4-26 and mean of $8.70 \pm 4.53$ in the control group $(\mathrm{p}<0.001)$. The perseverative errors \% scores were significantly higher among the patient group compared to control group. It ranged from 6-65 with mean of $22.70 \pm$ 15.27 in the patient group compared to a range of 6-20 and mean of $9.50 \pm 3.07$ in the control group $(\mathrm{p}<0.001)$.
The non-perseverative errors scores were significantly higher among the patient group compared to control group. It ranged from 3-70 with mean of $25.03 \pm 17.28$ in the patient group compared to a range of 3-24 and mean of $7.97 \pm 4.56$ in the control group $(p<0.001)$. The non-perseverative errors $\%$ scores were significantly higher among the patient group compared to control group. It ranged from 4-55 with mean of $20.73 \pm$ 13.12 in the patient group compared to a range of 3-85 and mean of $11.20 \pm 14.38$ in the control group $(\mathrm{p}=0.010)$.

Table (7): Comparison between patient group and control group as regards Wisconsin card sorting Test

\begin{tabular}{|c|c|c|c|c|}
\hline Wisconsin Card Sorting Test & $\begin{array}{c}\text { Patient group } \\
(n=30)\end{array}$ & $\begin{array}{c}\text { Control group } \\
(n=30)\end{array}$ & t-test & p-value \\
\hline \multicolumn{5}{|l|}{ Category completed } \\
\hline Mean \pm SD & $4.37 \pm 1.77$ & $6.00 \pm 0.00$ & \multirow[t]{2}{*}{25.514} & \multirow[t]{2}{*}{$<0.001$} \\
\hline Range & $1-6$ & $6-6$ & & \\
\hline \multicolumn{5}{|l|}{ Conceptual level } \\
\hline Mean \pm SD & $56.63 \pm 19.76$ & $69.10 \pm 8.12$ & \multirow[t]{2}{*}{10.217} & \multirow[t]{2}{*}{0.002} \\
\hline Range & $16-88$ & $60-88$ & & \\
\hline \multicolumn{5}{|l|}{ Conceptual level\% } \\
\hline Mean $\pm \mathrm{SD}$ & $51.63 \pm 21.46$ & $78.03 \pm 6.54$ & \multirow[t]{2}{*}{41.531} & \multirow[t]{2}{*}{$<0.001$} \\
\hline Range & $13-90$ & $66-88$ & & \\
\hline \multicolumn{5}{|l|}{ Perseverative responses } \\
\hline Mean \pm SD & $27.97 \pm 25.16$ & $9.07 \pm 5.55$ & \multirow[t]{2}{*}{16.14} & \multirow[t]{2}{*}{$<0.001$} \\
\hline Range & $4-102$ & $4-32$ & & \\
\hline \multicolumn{5}{|l|}{ Perseverative responses\% } \\
\hline Mean \pm SD & $23.63 \pm 18.82$ & $9.73 \pm 3.98$ & \multirow[t]{2}{*}{15.656} & \multirow[t]{2}{*}{$<0.001$} \\
\hline Range & $5-80$ & $5-25$ & & \\
\hline \multicolumn{5}{|l|}{ Perseverative errors } \\
\hline Mean \pm SD & $27.20 \pm 20.30$ & $8.70 \pm 4.53$ & \multirow[t]{2}{*}{23.731} & \multirow[t]{2}{*}{$<0.001$} \\
\hline Range & $4-80$ & $4-26$ & & \\
\hline \multicolumn{5}{|l|}{ Perseverative errors $\%$} \\
\hline Mean \pm SD & $22.70 \pm 15.27$ & $9.50 \pm 3.07$ & \multirow[t]{2}{*}{21.558} & \multirow[t]{2}{*}{$<0.001$} \\
\hline Range & $6-65$ & $6-20$ & & \\
\hline \multicolumn{5}{|l|}{ Non perseverative errors } \\
\hline Mean \pm SD & $25.03 \pm 17.28$ & $7.97 \pm 4.56$ & \multirow[t]{2}{*}{27.366} & \multirow[t]{2}{*}{$<0.001$} \\
\hline Range & $3-70$ & $3-24$ & & \\
\hline \multicolumn{5}{|l|}{ Non perseverative errors \% } \\
\hline Mean \pm SD & $20.73 \pm 13.12$ & $11.20 \pm 14.38$ & \multirow[t]{2}{*}{7.196} & \multirow[t]{2}{*}{0.010} \\
\hline Range & $4-55$ & $3-85$ & & \\
\hline
\end{tabular}

t-Independent Sample t-test; $\mathrm{SD}=$ standard deviation; $\mathrm{n}=$ number 


\section{DISCUSSION:}

Idiopathic epilepsies without structural brain changes constitute a better model for evaluating the impact of disease-related characteristics and paroxysmal epileptic activity on cognitive functions than symptommatic epilepsies, and therefore investigations of various aspects of cognition in idiopathic epilepsies are very important ${ }^{(11)}$.

The present study investigated cognitive functions in idiopathic epilepsy collectively. In our sample there were 30 patients with idiopathic epilepsy; 15 patient with IGE with GTC only, 7 patients with JME, 6 patients with absence epilepsy (4 patients with CAE, 2 patients with JAE) and lastly 2 patients with rolandic epilepsy.

The baseline cognitive tests done before treatment showed statistically significance cognitive deficit in patient group compared to control group as regard intellectual level, visual memory and executive functions (Table 5, 6, 7).

Recent study by Zhang et al. ${ }^{(5)}$ supported our findings as they revealed significant affection of executive function in new onset idiopathic seizures without medication.

Similar findings by a meta-analysis of 26 studies of idiopathic epilepsy, which showed moderate to large reductions across all cognitive factors, with the greatest deficits in executive functions ${ }^{(12)}$.

Moreover; another analysis of 247 treatment-naïve patients with newly diagnosed idiopathic epilepsy; Forty-nine per cent showed impaired attention and executive functions, while 48 per cent showed memory defects and only 28 per cent showed unaffected attention, executive functions and memory ${ }^{(13)}$. Similar results were reported by several studies ${ }^{(14,15)}$.

Oostrom et al. ${ }^{(16)}$ in a study of 42 children with epilepsy only who were receiving mainstream education found that patients with idiopathic epilepsy at time of diagnosis and before treatment performed less well than healthy classmate on measures of learning, memory, attention and behavior.

Several studies reported antecedent cognitive impairment before first recognized seizure could be related to microstructural and functional alteration of brain at onset of epilepsy, suggest the presence of a common neurobiological mechanisms between epilepsy and cognitive morbidity ${ }^{(17)}$. Therefore, presence of common microstructural abnormalities could explain the present findings.

Other pathological abnormalities like abnormal pattern of apoptosis, channelopathies, bad synapses and improper dendrites are suggested as an underlying disturbance related to the cognitive abnormalities $^{(18)}$.

Hutchinson et al. ${ }^{(19)}$ and Pulsipher et al. ${ }^{(20)}$ confirmed microstructural abnormallities in the white and gray matter of the frontal, parietal, temporal, occipital lobes, thalamic region and posterior corpus callosum in children with idiopathic newonset epilepsy.

Differences from current results could be explained by different tools applied and different baseline cognitive.

As the impairment of executive functions is very important in children and adolescents with epilepsy for its impact on the learning process, we suggest a neuropsychological evaluation in patients with idiopathic generalized epilepsy early in the course of the disease in order to provide adequate intervention when necessary.

\section{Conclusion:}

Patients with idiopathic epilepsy showed significant impairment of cognitive functions including (intellectual abilities, visual memory and executive functions) at onset of the disorder and before starting treatment. And this highlights the 
importance of early identification of cognitive deficits and early treatment and control of epilepsy that will lead to improvement of cognitive functions.

\section{REFERENCES:}

1. Berg A.T., Berkovic, S.F., Brodie M.J., et al. (2010): Revised terminology and concepts for organization of seizures and epilepsies: report of the ILAE Commission on Classification and Terminology, 20052009. Epilepsia; 51 (4): 676-685.

2. Martland T. C. and Helen J. (2009): Best clinical and research practice in pediatric neurology. Epilepsy \& Behavior; 15: 551 554.

3. Mandel baum, D., E, G. Burack D., et al. (2009): Impact of antiepileptic drugs on cognition, behaviour, and motor skills in children with new-onset, idiopathic epilepsy. Epilepsy \& Behavior; 16: 341 344.

4. Soria C., Callu D. et al. (2008): Parental report of cognitive difficulties, quality of lie and rehabilitaiton in children with epilepsy or treated for brain tumour. Developmental Neurorehabilitation; 11(4): 268 - 275.

5. Zhang T., Chen L., Wang Y., et al. (2018): Epilepsy and behavior; 79: 205-212.

6. Hermann B., Jones J., Sheth R., et al. (2006): Children with new-onset epilepsy: neuropsychological status and brain structure Brain; 129, 2609-2619.

7. Rathouz P.J., Zhao Q., Jones J.E., et al. (2014): Cognitive development in children with new onset epilepsy. Dev Med Child Neurol; 56(7):635-41.

8. Witt J.A., Werhahn K.J., Krämer G., et al. (2014): Cognitive-behavioral screening in elderly patients with new-onset epilepsy before treatment. Acta Neurol Scand; 130 (3):172-7.

9. Witt J.A., Glöckner C., Helmstaedter C. (2012): Extended retention intervals can help to bridge the gap between subjective and objective memory impairment. Seizure; 21:134-40.

10. Wechsler D.I. (1991): Examiner's manual; Wechsler intelligence scale for children, third edition. Psychological Corporation, New York.

11. Hommet C., Sauerwein H.C., De T.B. and Lassonde M., (2006): Idiopathic epileptic syndromes and cognition. Neurosci. Biobehav. Rev.; 30, 85-96.

12. Loughman A., Bowden S. and D'Souza W. (2014): Cognitive functioning in idiopathic generalised epilepsies: a systematic review and meta-analysis. Neurosci Biobehav Rev; 43: 20-34.

13. Witt J.A. and Helmstaedter C. (2012): Should cognition be screened in new-onset epilepsies? A study in 247 untreated patients. J Neurol; 259:1727-31

14. Pascalicchio T.F., Filho G.M., Noffs M.H., et al. (2007): Neuropsychological profile of patients with juvenile myoclonic epilepsy: a controlled study of 50 patients. Epilepsy Behav; 10:263-7.

15. Gelžinienè G., Jurkevičienė G., Marmienè V., et al. (2011): Executive Functions in Adolescents With Idiopathic Generalized Epilepsy Medicina (Kaunas) ;47(6):313-9

16. Oostrom K.J., van Teeseling H., Schouten S.A., et al. (2005): Dutch Study of Epilepsy in Childhood (DuSECh), Three to four years after diagnosis: cognition and behaviour in children with 'epilepsy only'. A prospective, controlled study. Brain. 128(7): 1546-55.

17. Kim E.H. and Ko T.S. (2016): Cognitive impairment in childhood onset epilepsy; uptodate information about its causes. Korean journal of paediatrics: 59(4):155164.

18. Kang S.H., Yum M.S., Kim E.H. et al. (2015): cognitive functions in childhood epilepsy: importance of attention deficit hyperactivity disorder. Neurol. 11: 20-25. 
تقييم الوظائف المعرفية لاي مرضي الصرع الذاتي حديثي التثخيص

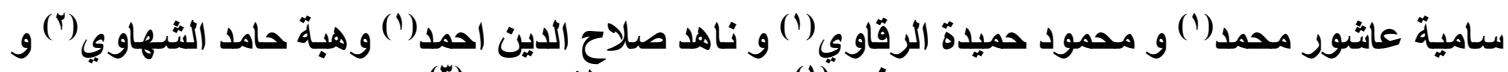

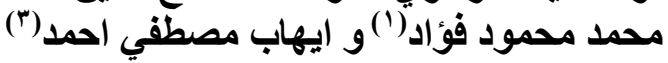

$$
\begin{aligned}
& \text { ا - قسم المخ و الاعصابـ كلية الطب-جامعة عين شمس } \\
& \text { r- ـ قسم الطب النفسي_ كلية الطب-جامعة عين شمس }
\end{aligned}
$$

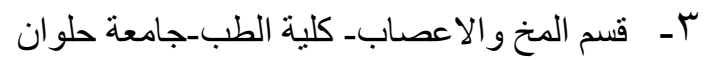

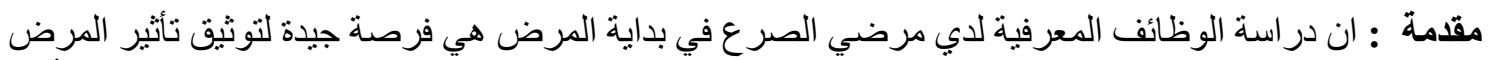

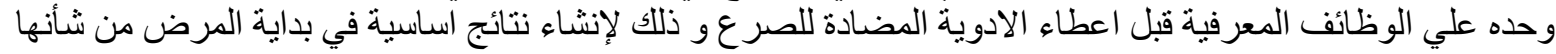

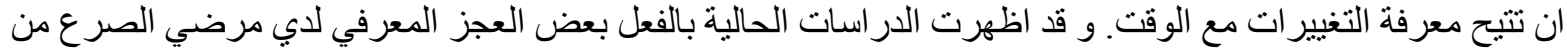

الاطفال و الكبار في بداية المرض و قبل اخذ اي ادوية مضادة للصرع.

هذف البحث : تهدف دراستنا إلى تقييم الوظائف المعرفية بما في ذلإلك (الذكاء و الذاكرة البصرية و الوظائف التنفيذية) في المرضى الذين يعانون من الصر ع الذاتي مجهول السبب عند بداية الاضطر اب قبل العبل العلاج بالعقاقير أو خلال أسبوع

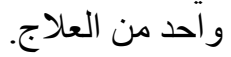

$$
\begin{aligned}
& \text { المرضي وطريقة البحث : خضع المرضي الذين شملهم البحث الي }
\end{aligned}
$$

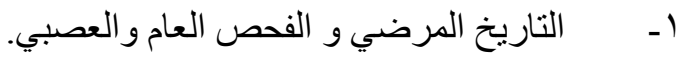

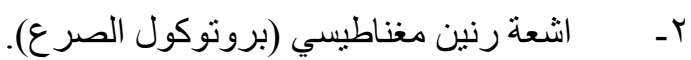

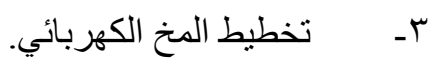

$$
\begin{aligned}
& \text { ع- اختبار ات الوظائف المعرفية وتنشمل: } \\
& \text { - اختبار ويكسلر لقياس مستوي الذكاء. }
\end{aligned}
$$

- م ا اختبار بنتون لقياس الذاكرة البصرية والاحتفاظ البصري.

$$
\text { - اختبار ويسكونسين لقياس الوظائف التنفيذية للمخح. }
$$

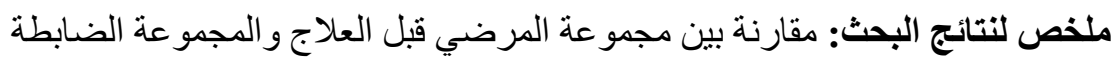

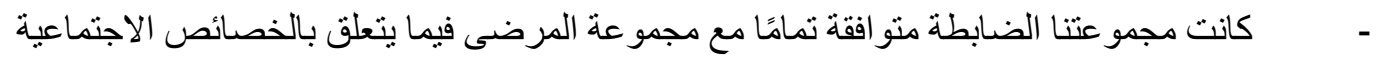

$$
\text { و الديمو غر افية (العمر والجنس وسنوات النغات التعليم). }
$$

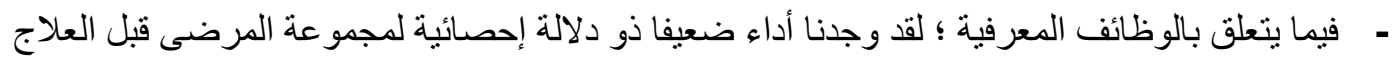

في جميع الاختبار ات ( اختبار ويكسلر للذكاء ، واختبار بنتون للاحتفاظ البصري والتاني واختبار فرز بطاقة لويسكونسن لاختبار الوظائف التنفيذية للمخح).

خلاصة البحث: توصل البحث الي وجود قصور بالوظائف المعرفية مشتملة (مستوي الذكاء و الذاكرة البصرية

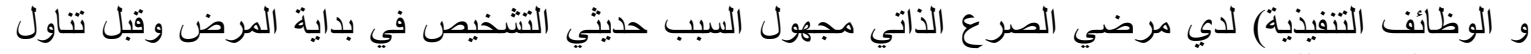



